\title{
George M. Duck Lecture
}

\section{Yasir Naqvi*}

The Hon. Yasir Naqvi, Attorney General of Ontario, delivered the George M. Duck Lecture at the University of Windsor Faculty of Law on February 28, 2018.

I would like to acknowledge that we are meeting today on the traditional lands of the Three Fires Confederacy, which is comprised of the Ojibway, the Odawa, and the Potawatomi.

It is important that we recognize the long history of First Nations and Métis Peoples in Ontario and that we continue to show them respect today.

It is wonderful to be here at the University of Windsor Law School as you celebrate your $50^{\text {th }}$ year.

Thank you to the University for allowing me the distinct honour of presenting this year's George M. Duck lecture, a tradition that almost extends to the birth of the law school itself.

\section{GEORGE M. DUCK LECTURE SERIES}

So many significant figures of our Canadian legal and political landscape have stood within these very walls to deliver this lecture.

Jean Chrétien and John Turner, when each was the federal Minister of Justice, Supreme Court Justice Rosalie Abella and Roberta Jamieson, the first Indigenous woman to earn a law degree in Canada, and Ontario's Ombudsman at the time.

I am honoured and humbled to join this distinguished group.

\section{LESSONS FROM MY YOUTH}

As a law student 20 years ago, I would never have thought my career would lead me here and certainly not as a kid growing up in Karachi.

When I was growing up in Karachi, my parents - who were both lawyers - were involved in the prodemocracy movement. Pakistan, as you may know, in late 1970s and 1980s was governed by a military regime. It was a country where democratic institutions and traditions were systematically and deliberately weakened.

In the early 80 s my father participated in a movement that had the sole purpose of restoring democracy in our country. One day, my dad set out to lead a peaceful pro-democracy march - even though the government banned protests of more than five people. Well, 500 showed up that day. Dad was jailed as a political prisoner for nine months.

That part of my life made me a witness and participant to some events that had a profound impact on me: my father's arrest and his unlawful trial held in a military court, my mother's struggle to secure his basic rights while he was in detention, and our family's quest to visit my dad every weekend in a notorious jail almost 200 kilometres away from where we lived.

Yasir Naqvi served as the Member of Provincial Parliament (MPP) for Ottawa Centre from 2007 to 2018 . In that time he served as the Attorney General of Ontario, Government House Leader, and as the Minister of Labour and Minister of Community Safety and Correctional Services. 
My father was not the only one - thousands were arrested and detained during that period simply because they demanded free, open and multi-party democratic elections.

Fortunately for us, my parents made a bold - and very difficult - decision to move our family to Canada. In my father's case, he wanted to come to Canada because he wanted his children to be citizens of the world. He wanted us to live in a society where we were free to do whatever we wanted. In my mother's case, she wanted her daughter to be equal to her two sons. She wanted equality for herself and for my sister.

Now, when I normally tell that story, I sometimes see shock on faces in the crowd. But for many of you here today, I imagine a story like that one is not so unfamiliar.

Maybe you heard a story like that one from your parents, or grandparents - or maybe you were the one questioning your situation and taking steps to change your life for the better. What I know is that the experiences I had in my childhood shaped me and my belief system. Those experiences are the reason I believe in the supremacy of the rule of law, the guarantee of individual rights, and that a justice system should treat everyone equally.

It is the reason that I am always inclined to question the status quo - not defend it.

\section{HISTORY OF THE UNIVERSITY OF WINDSOR FACULTY OF LAW \& ACCESS TO JUSTICE}

And just like how my experiences affect how I now see things, the same is true for all of us and our institutions. Our future cannot be separated from our past, one influences the other.

Fifty years ago, the first Dean of Windsor Law School, Dr. MacGuigan, spoke to a group of Rotarians about his vision for the new law school he was about to lead.

He said, "People's law... not lawyers' law... will be emphasized when school begins classes in September."

It was a bold statement. But what does "people's law" mean? I believe that, at least in part, Dean MacGuigan was speaking directly to what would become a core focus of your school: access to justice.

It was important half a century ago. But the importance - the urgency - of this cause has grown exponentially. In fact, I would say that access to justice is simply the most central and relevant challenge facing the broader legal community today.

You do not need to look very hard to find examples of the obstacles many Canadians face in obtaining equal access to justice. Whether the challenges are financial or geographical; whether they relate to ethnicity or gender or sexual orientation; problems with the current system - the status quo - exist.

But then, so too do the opportunities for change. Because though our system is one steeped in tradition - tradition that I and many others value immensely - the inequities can be hard to see, and the need for change hard to face. But it cannot be ignored. To be clear, tradition in our institutions is not a bad thing far from it. Our justice system is one of the cornerstones of our democracy, and as the son of a political prisoner who fought for the same democratic rights we all enjoy here in Canada, I am incredibly proud of our democratic institutions, and I feel an immense responsibility to protect them.

But that does not mean I shouldn't ask... could they be better? That does not mean we can't look outside the box for new solutions to old problems.

To me, protecting our justice system does not mean that we should preserve it, as is, like a museum exhibit. It means we need to prepare the system to adapt, or risk losing the confidence of the people it's meant to serve. And that requires asking some tough questions and being open to the answers. 
Over the past year and a half, since I was appointed Attorney General, we have been asking ourselves those questions. Does everyone have the same experience when they interact with the justice system? Or, do some people have a different experience based on the language they speak, the colour of their skin, or their mental health status? Can the current delay in the system be solved by new technology and resources? Or will it require a more fundamental shift?

Now, I can tell you from experience that those kinds of questions can make people uncomfortable especially when we are talking about an institution as integral to our democracy as our justice system.

But that is not an excuse to push the questions - and the issues that led to them - down the road. Especially when we know that we need to be forward thinking in order for our justice system to flourish in 10,20 or 50 years' time.

Those of you who know about some of the work that we are doing at the Ministry of the Attorney General know that we have a lot on the go, but we identified three major areas in need that had to take priority:

First, the Jordan challenge - we recognized that serious delays and trials that take too long undermine not only the criminal justice system but our public safety as a whole.

Second, our bail system - because even if we could get the courts moving at a faster pace, we knew we must address the reality that there are far too many low risk and vulnerable individuals sitting in jails just waiting for their trial.

And third, the overrepresentation of Indigenous people in the justice system as victims and offenders, recognizing the circumstances and barriers faced by all vulnerable and disadvantaged persons who enter the system.

We knew that solutions meant to address problems of delay and bail are not a one-size-fits-all - and that we would need to ensure that any new programs serving Indigenous people would be culturallyresponsive and appropriate. Of course, each of these are major, transformative undertakings in their own right. Each require us to build new, dedicated systems of support. And in many cases they require that we be open to larger, systemic changes if we are to make a meaningful impact.

We have been working with our colleagues from across the justice sector, Indigenous leaders, and all levels of government to do just that. Now I'm the first to admit that the pace of change may not be as fast as we want it to be, especially when we contrast it with the rapid pace of technological advancement.

But we have made some truly remarkable progress to reduce trial delays and create a faster, fairer justice system - one that better serves the needs of Ontarians - no matter who they are, where they come from, or what language they speak.

\section{THE JORDAN CHALLENGE}

The challenge of delay in our courts is far from new, in fact I'm sure it's been discussed in classrooms just like this one for many years. And yet the problem persisted. On this issue, our history points to what the Supreme Court called in their Jordan decision, "a culture of delay and complacency." Everyone, from elected officials, to the courts, the bar and police, had a role to play.

It has been a long - and at times tough - journey in the aftermath of that decision.

And although Jordan has been difficult for many, in my view, it has also presented us with an opportunity. An opportunity to come together and make meaningful and lasting structural reforms to our criminal justice system. An opportunity to make the next 50 years of the justice system, better, faster, and more equitable than the last. I really do believe that we have seized that opportunity.

At the end of 2016, I announced significant and sustained funding for Ontario's criminal justice system. An additional \$25 million a year to be exact. Funding dedicated to new judges, more Crowns, defense 
counsel, and court staff and additional resources for technology and innovation that would help alleviate pressures on our overburdened system.

Now, these infrastructure and technological updates are absolutely necessary - especially in the wake of Jordan. But at the end of the day, they are upgrades to the physical structures of our system - and we know that change requires a more fundamental shift.

Because we also know that there are certain communities that have disproportionately faced barriers accessing justice. So while technology and infrastructure upgrades undoubtedly play a role in reducing delay, if we do not examine how people actually interact with the system, access to justice will remain out of reach for some.

\section{BAIL ACTION PLAN}

That is why tackling our second challenge - bail - was essential. Bail is a critical stage of the justice process, and whether or not a person has access to bail can have serious impacts on the outcome of their case.

This first entry point into the criminal justice system often - if not always — defines a person's overall experience. And when we asked ourselves if all people experience the justice system the same way, the harsh answer was no.

The reality is that too many of the people in our correctional facilities are on remand - far more than the number of people actually convicted of an offense. Too many are vulnerable, low-risk people, or have mental health and addictions issues, and far too many, a disproportionate number, are racialized or Indigenous. Of these individuals, a large number end up on remand because they just do not have the social or financial supports necessary to get or stay out on bail. For some, it is an ongoing cycle. And for many, remaining in the system can impact their ability to earn an income, and interrupt the care and support they need.

As a province, and as guardians of our justice system, I know that we can and must do better. And we knew that lasting and meaningful change would require more than resources, new tech, or adding staff. It would require structural and systemic changes. We also knew we could respect the traditions of the institution, but discover new solutions to make necessary changes. That meant reaching out to some of the most senior and respected persons in the criminal justice system, including a former Chief Justice to lead consultations and provide us with advice on how to modernize the Crown policy on bail. This resulted in real structural changes to how bail is handled in the province.

The new bail directive focuses on the right to reasonable bail, and emphasizes that bail recommendations should start with the least restrictive form of release.

We also know that when individuals are connected with appropriate resources and supports, they are more likely to achieve stability in the community and less likely to reoffend, which is why we've made key investments in these areas. We believe long term solutions must look at truly ending the cycle of incarceration - not simply speeding up the process to get there. 


\section{INDIGENOUS JUSTICE}

And as we work to break that cycle, we must acknowledge that many of the people caught in it - far too many - are Indigenous. I know this is a problem — and it has been a problem for many decades. But that cannot be a justification to delay action. In fact, I would argue that it is an even more compelling reason to act with urgency.

So, as we continue the journey of reconciliation with Indigenous peoples, and work to build longlasting relationships, we are collaborating with Indigenous leadership and communities to reduce incarceration rates and remove barriers to accessing justice.

\section{A. Jury Representation}

Certainly, the issue of Indigenous representation on juries is a major part of the national discourse right now. I can tell you that Ontario is deeply committed to improving the representation of Indigenous people on jury rolls. Our government appointed Justice Frank Iacobucci to provide us with advice on enhancing the representation of First Nations people on Ontario juries. And in keeping with Justice Iacobucci's recommendations, the government also created the Jury Review Implementation committee, named Debwewin. Debwewin had a three year mandate to look at Justice Iacobucci's recommendations and provide us advice on how to implement them. And while they were grappling with those complex issues, we got to work on what we could implement immediately.

The first thing we did was create a new division within my ministry, which is dedicated to advancing Indigenous justice issues - the first and only of its kind in Canada. We also amended the Juries Act to extend the reply period for completed juror questionnaires from five days to 30 and funded two Indigenous Language Court pilot projects to improve criminal justice services for Indigenous language speakers in Ontario.

The work in this area is far from over, and while I am disheartened at how long it has taken us to reach this point, I am glad the nation is now paying attention. This is a moment of change in our history, and when we look back in 50 years I want to know that we did not hesitate, that we seized this moment and drove change.

\section{B. Restorative Justice}

But we know juries are not the only area within the justice system where barriers exist. And in order to be responsive and truly address the unique barriers and needs of Indigenous people, we need to tailor our justice services.

Because, as I'm sure you all agree, when it comes to Indigenous peoples' experience of the justice system - we simply cannot afford the next 50 years to in any way resemble the last 50 . That's why our government is supporting Indigenous communities as they design, develop and deliver programs that reflect Indigenous values and laws. It is important for me to emphasize that these programs are not government-designed and operated programs. Rather, they are designed and delivered by Indigenous communities and organizations for Indigenous people.

Indigenous communities have developed and are delivering pre-charge and post-charge diversion programs which are informed by Indigenous cultural world views, laws and dispute resolution processes. This represents a significant change for Ontario. These programs are focused on healing and restoration.

They provide a meaningful path forward to enable Indigenous people involved with the criminal justice system to address the root causes of their crimes, so that they can create a new path forward in their lives.

Because of the diversity of Indigenous communities across Ontario, each program is tailored by the community or communities that it serves. And this tailored approach is intentional. All together, these 
represent a significant shift in the way our province delivers justice to Indigenous communities.

\section{Community Justice Centres}

But we hope this shift in how we understand justice is not isolated to restorative justice initiatives in Indigenous communities. We believe these principles can play a critical role in the system overall as it evolves. Currently, when it comes to criminal matters, the status quo most often means going to court. But, for those who are vulnerable, this route through the traditional criminal justice system may be the least likely way to address their specific needs. And it may just serve to maintain the revolving door of offence and re-offence.

This is why our government is exploring the potential development of Community Justice Centres in our communities. These centres place restorative or therapeutic courts with culturally-relevant community-based services and agencies altogether to provide holistic, wrap-around services, enabling closer collaboration between justice, health, and social service partners. These centres help vulnerable offenders to address factors that may contribute to criminal behaviour - factors like poverty, homelessness, and mental health and addiction issues. As you may know, in some courthouse locations, we have specialized Drug Treatment Courts - including one right here in Windsor.

The success of these specialized courts - which are getting a lot of positive attention here locally just goes to show the benefits of connecting vulnerable individuals to services and providing communitybased solutions. Community Justice Centres could build on this success. They have the potential to extend restorative justice principles to a greater number of vulnerable offenders.

When individuals have this type of access to justice, and are connected with appropriate resources and supports, they are more likely to achieve stability in the community and less likely to commit further criminal offences. I hope to have more to tell you about these and other initiatives in the near future - so please stay tuned!

\section{CONCLUSION}

I know that we are going to be opening the floor to questions shortly, but before we get to that, what I can tell you is this: if I could predict what the next 50 years would be like with a high degree of accuracy, well, I would be in a different business!

But what I do know for sure is that change is happening all around us, in every sector and while such change can often be disruptive and tremendously challenging for those living and working through it, it can often reap incredible rewards.

The justice system must work hard - not only to keep up, but to be a part of that change; to lead that change.

The legal profession that you have chosen to join is full of positive, progressive thinkers, people who don't just react to the changing world around them - but respond to it, are inspired by it, and even influence it.

Working together with our partners, with our communities, with you - the newest generation of lawyers - I know we can make our justice system stronger and better than it has ever been.

My vision - and hopefully yours - is simple but broad.

In the next 50 years, when people say the justice system works quickly and efficiently, they don't say it with a smirk and a hint of irony. 50 years from now, when citizens of this province think about equality and diversity, for poor and rich, no matter race, religion or sexuality, indigenous or immigrant, they will be certain that it exists within the justice system. It's my hope that in 50 years, when someone enters the 
criminal justice system they don't come out worse than when they went in. They will be provided with tailored, community-based supports to address what led to the violence or victimization.

So, as you enter this next 50 years, I encourage you take hold of that vision, and act on it. Challenging the status quo as you find it, in whatever field of law you find yourself.

For my part, I promise that the Ministry of the Attorney General and this government will partner with you to make our justice system stronger, more responsive, and better than it has ever been.

It is an exciting time to be in this profession. I look forward to what comes next.

Thank you. 